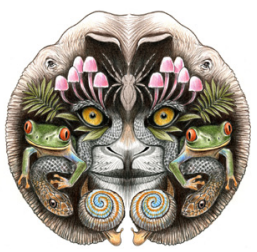

ISSN

Print 0974-7893
Online 0974-7907

During July 2010 a survey was conducted to explore the microfungal diversity in the natural forests of Tamhini Ghats situated in the northern part of the Western Ghats, India, at $18^{\circ} 27^{\prime} \mathrm{N} \& 73^{\circ} 25^{\prime} \mathrm{E}$.

OPEN ACCESS The average altitude of the area is $600 \mathrm{~m}$, while the surrounding hilltops range from $850-1050 \mathrm{~m}$. The hilly regions show little primary evergreen forest restricted to sacred groves and comparatively more secondary evergreen and moist deciduous forests (Dahanukar \& Padhye 2005). Tamhini Ghats and surrounding areas are rich and diverse for their fungal diversity; many new species including a recent new genus Tamhinispora Rajeshkumar \& Rahul Sharma were identified from Tamhini Ghat valleys (Rajeshkumar et al. 2011a,b; Rajeshkumar \& Singh 2012; Rajeshkumar \& Sharma 2013). An obscure species of Phalangispora Nawawi \& Webster form sporodochia with stauroconidia with branches radiating or up (Seifert et al. 2011) and sporodochial setae surrounding the conidiomata was found on fallen leaves of Mangifera indica.

The genus Phalangispora was described by Nawawi \& Webster (1982) for a fungus having branched tetraradiate conidia collected from the water forms of Ulu Gaombak in Malaysia and sporulating cultures on 2\% Malt Extract Agar (IMI 256650). They established the genus Phalangispora with key characteristics 'Mycelium primo subhyalinum, postea brunneo olivaceum, septatum, Conidiomata (sporodochia) pustulata aut obconica primo albida postea olivacea, sicca apparentia, laxa, ca. $5 \mathrm{~mm}$ lata, ad basim cum 1-5 seris, Setare

\section{A REAPPRAISAL OF THE FUNGUS GENUS PHALANGISPORA WITH THE REDISCOVERY OF P. BHARATHENSIS ON LEAF LITTER OF MANGIFERA INDICA FROM THE NORTHERN WESTERN GHATS, INDIA}

\section{K.C. Rajeshkumar}

Mycology \& Plant Pathology, MACS-Agharkar Research Institute, Agarkar Road, Pune, Maharashtra 411004, India rajeshfungi@gmail.com

brunneae vel attae, septatae, parietibus crassis, subulatae, Conidia ramose, septate, constricta, brunnea'; with type species $P$. constricta Nawawi \& Webster. The present study aims at an addition of new characteristics found in this genus in nature which is unique in the new strain and a rediscovery of $P$. bharathensis Keshava Prasad \& Bhat with a varied conidial and conidial chain dimensions found on a new substrate (dead fallen leaves of Mangifera indica), collected from Tamhini Ghats, Maharashtra State, India.

Methods: Isolates and morphology: Sporodochia of the fungus were isolated from the lower surface of fallen leaves and observed under a Nikon Binocular stereo microscope (Model SMZ-1500 with Digi-CAM, Japan). For morphotaxonomic studies and photomicrographs an Olympus CX-41 (Japan) microscope was used. Conidia, conidiophores, and setae were measured using an ocular micrometer. The specimens were deposited in Ajrekar Mycological Herbarium (AMH 9580), Agharkar Research Institute, Pune, India.

DOI: http://dx.doi.org/10.11609/JoTT.03891.6278-81

Editor: R.K. Verma, Tropical Forest Research Institute, Jabalpur, India.

Date of publication: 26 August 2014 (online \& print)

Manuscript details: Ms \# 03891 | Received 30 December 2013 | Final received 29 July 2014 | Finally accepted 02 August 2014

Citation: Rajeshkumar, K.C. (2014). A reappraisal of the fungus genus Phalangispora with the rediscovery of $P$. bharathensis on leaf litter of Mangifera indica from the northern Western Ghats, India. Journal of Threatened Taxa 6(9): 6278-6281; http://dx.doi.org/10.11609/JoTT.03891.6278-81

Copyright: @ Rajeshkumar 2014. Creative Commons Attribution 4.0 International License. JoTT allows unrestricted use of this article in any medium, reproduction and distribution by providing adequate credit to the authors and the source of publication.

Funding: I thank the Department of Science and Technology (DST), Government of India, New Delhi for providing financial support (under scheme No. SP/SO/PS-55/2005).

Competing Interest: The authors declare no competing interests.

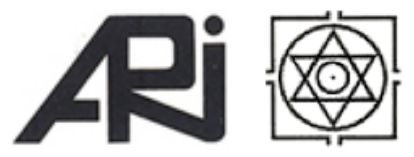

Acknowledgements: I indebted to Pedro W. Crous, Director, Centraalbureau voor Schimmelcultures, Utrecht, The Netherlands and Dr. Andrew Minnis, Systematic Mycology \& Microbiology Lab., USDA, ARS, Beltsville, U.S.A., for advice and suggestions. Dr. Amy Y. Rossman Systematic Mycology \& Microbiology Lab., USDA, ARS, Beltsville, U.S.A., for encouragement. Thanks are also due to the Director, Agharkar Research Institute, Pune for providing facilities. 


\section{Results}

Phalangispora bharathensis Keshava Prasad \& Bhat 2002 (Image 1 and Fig. 1)

Type description: Terrestrial litter hyphomycete. Colonies effuse, olivaceous brown to dark brown. Mycelium partly superficial, hyphae 2.5-3.5 $\mu \mathrm{m}$ wide. Conidiomata sporodochial, solitary, pulvinate, slightly elevated, with 8-16 setae arising from the margin of the base. Setae subulate, acute at apex, septate, thick walled, dark brown, smooth, 300-400 × 7-10 $\mu \mathrm{m}$. Conidiophores mononematous, arising in groups, septate, 1-2 times branched, 15-30 $\mu \mathrm{m}$ long, 2-4.5 $\mu \mathrm{m}$ wide. Conidiogenous cells polyblastic, terminal, hyaline, smooth with denticulate scars at the rounded apex. Conidia hyaline, smooth, aseptate, in 2-3 branched chains of 75-85 $\mu \mathrm{m}$ long, 2.5-4 $\mu \mathrm{m}$ wide, connected by

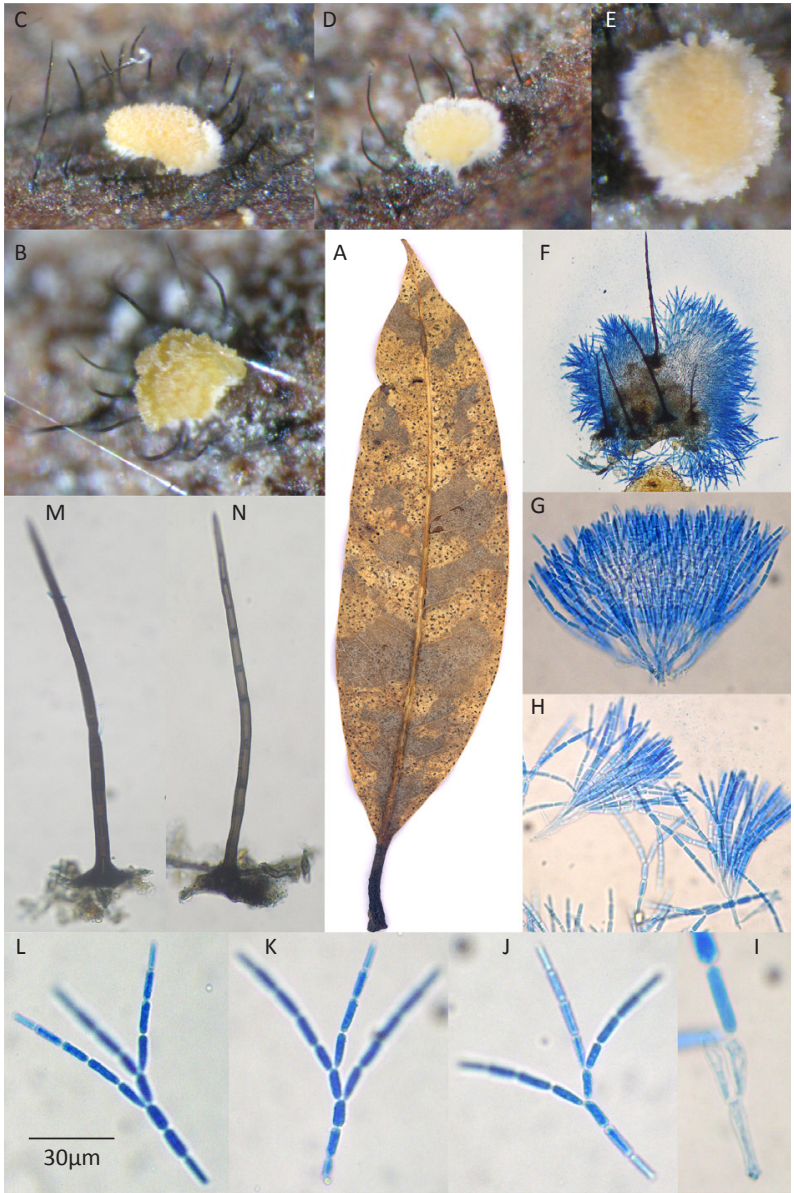

Image 1. Phalangispora bharathensis, AMH 9580.

A - Habit; B-E - Sporodochia with surrounding setae; F - Sporodochia top view; G-H - Conidiophores bunches with setae and conidia;

I - Conidial attachment to condiogenous cells; J-L - Conidia; M-N - Setae. ㄷ K.C. Rajeshkumar narrow isthmi, uniseriate below, bi to tri seriate above, with branches arising from the third or fourth cells of the main axis, of two types; apical or basal cells conical to obclavate, 7-9 $\times 2.5-3 \mu \mathrm{m}$; intermediate cells cylindrical with truncate ends, $8-10 \times 2.5-4 \mu \mathrm{m}$; in mass initially whitish, later becoming pale brown.

Type specimen: Herb No. IMI 387091, 11.iii.1999, on decaying leaves of Holigarna arnotiana (Wt. \& Arn.) Hook.f., Cotigao Wildlife Sanctuary, Goa, India, coll. Keshava Prasad.

Present collection: $\mathrm{AMH}$ 9580. On fallen decaying leaves of Mangifera indica, Mycelium semi-immersed, 2-3 $\mu \mathrm{m}$ wide, pale brown, septate, branched, thin walled, smooth. Conidiomata sporodochial, flattened, yellowish central part with white to off white marginal area, spherical or hemispherical, 100-240 $\mu \mathrm{m}$ diam. Setose, setae $155-250 \times 6-7.25 \mu \mathrm{m}, 9-28$ in numbers per sporodochia, arranged around the sporodochium, pale to dark brown or blackish, tapering towards the acute apex, paler towards tip, septate, septa thick walled, base wider 12-15 $\mu \mathrm{m}$, swollen with rhizoid like structures, wall smooth and thick. Conidiophores present, highly branched, with primary and secondary branches, cylindrical, hyaline smooth, primary branches 16-25 × 3-3.5 $\mu \mathrm{m}$, secondary branches 8-12 × 2.5-3.5 $\mu \mathrm{m}$, Phialides cylindrical, smooth, hyaline $6-8 \times 2.5-3$

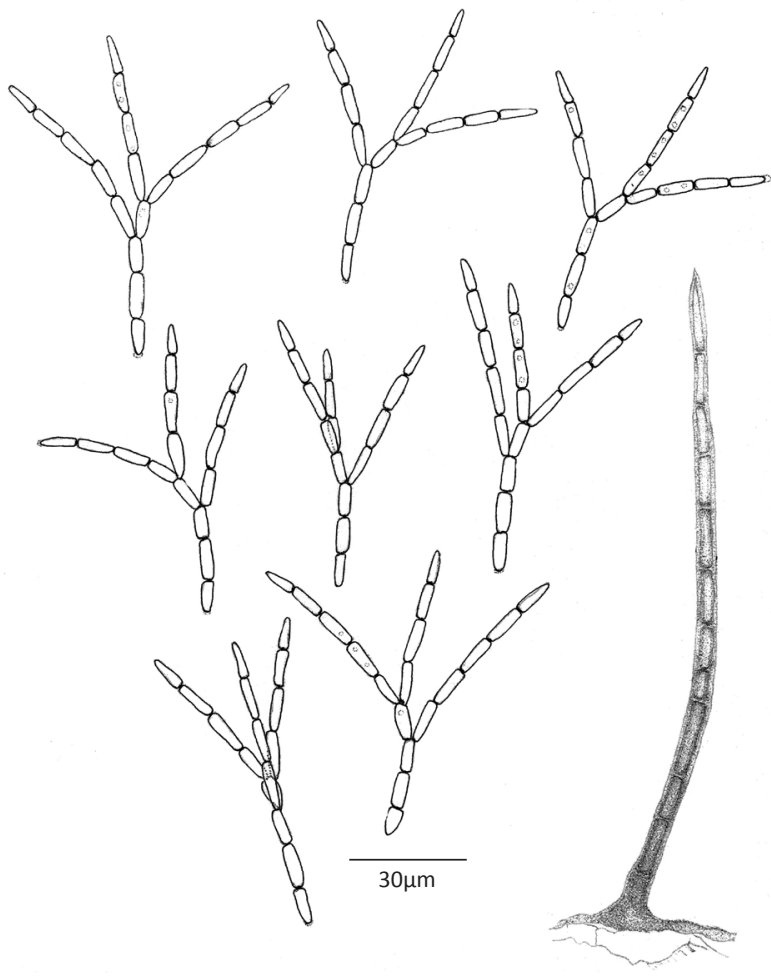

Figure 1. Phalangispora bharathensis, AMH 9580.

A - Variation in conidial shape; B - Setae. 
$\mu \mathrm{m}$, tip slightly bulged with two apical conidiogenous loci. Conidia holoblastic, hyaline, connected in chain through isthmi, branched, constricted at septa, overall conidia measure up to $74-87.5 \times 2-4.5 \mu \mathrm{m}$, uniseriate below, bi to tri seriate above, with branches arising from the third and/or fourth cells of the main axis, conidia are two types; apical or basal cells conical, 8-11.3 $\times$ 2-3.3 $\mu \mathrm{m}$; intermediate cells cylindrical with truncate ends, $9.5-12.5 \times 3-4.5 \mu \mathrm{m}$. Y shaped conidia were also occasionally observed.

Material examined: AMH 9580, 30.vii.2010, on fallen decaying leaves of Mangifera indica L. (Anacardiaceae), Tamhini Ghats, Maharashtra State, India, coll. K.C. Rajeshkumar.

Teleomorph: Unknown.

Known distribution: Validly published from Malaysia and India

Notes: The arrangement of dark brown, septate sporodochial setae surrounding the sporodochia is a unique character in this strain that differentiates it from all the species so far recorded in this genus.

Discussion: Genus Phalangispora is a unique setose sporodochial hyphomycete producing hyaline smooth, unicellular conidia connected by narrow isthmi in branched chains on polyblastic, discrete conidiogenous cells and short, thin walled, hyaline, septate conidiophores. While authenticating the type culture of Phalangispora in IMI (IMI 256650), BC Sutton (Nawawi \& Webster 1982) had an opinion that the isolate made from the forms in Malaysia belongs to a group of genera which include Wiesneriomyces Koord., Speiropsis Tubaki, Gliophragma Subram. \& Lodha and Pseudogliophragma Phadke \& V.G. Rao. However, Phalangispora was related to Speiropsis, having branched conidial morphology, but differs from it in conidiomatal structure. He also mentioned the difference found in the presence or absence of setae in these genera; Speiropsis and Pseudogliophragma lack setae; however, Wiesneriomyces have sporodochial setae with simple chained conidia. Prior to this inventory, the conidia of this fungus have been reported from many different countries including Nigeria (Ingold 1959), Ghana (Dixon 1959), Sierra Leone (Le-John 1965) Japan (Miura 1974) and Indonesia (Nayo 1975) but a valid recognition was not made.

Based on the sporodochial development of $P$. constricta on dry Agar, Nawawi \& Webster (1982) predicted the possibility of this fungus distribution in nature out of water. Later on, Nawawi (1985) reported that the fungus is semi-aquatic that readily grows on decaying leaves in a moist chamber. While describing a new species of Phalangispora, P. nawawi Kuthub. (holotype, IMI 312357, Lepar Forest Reserve, Pahang, Malaysia July 1986), Kuthubutheen (1987) confirmed the occurrence of the sporodochia of the type species in natural habitats in Malaysia. P. nawawi was erected based on the difference in size of the individual conidia, conidial chain and number of individual cell in the main axis and lateral branches. In P. nawawi the conidial chains were smaller and number of cells was fewer than $P$. constricta. The third species of Phalangispora, $P$. bharathensis was added from the Western Ghats of India as a terrestrial litter hyphomycete on Holigarna arnotiana (Anacardiaceae) from Cotigao Wildlife Sanctuary, Goa, India (IMI 387091). It was the first published species added to the genus Phalangispora outside Malaysia and first record of this genus from India (Prasad \& Bhat 2002). The major differences in conidial characteristics of these species are given in Table 1.

In the present study the length of setae in the new strain of $P$. bharathensis was found to be shorter though the arrangement of setae was unique, surrounding the sporodochia. Also, the number of setae is much higher at 9-28 per sporodochia. All the species so far recorded under Phalangiospora have been described with sporodochia with basal setae; especially in $P$. bharathensis 8-16 setae arise from the margin of the sporodochial base. The illustrations provided in $P$. nawawi and $P$. bharathensis stated the same. Similar characteristics were validly considered even for differentiation of stauroconidia forming genus like Fumagopsis Speg. and Tridentaria Preuss in the past. Spegazzini (1910) established the genus Fumagopsis with a monotypic species under this genus $F$. triglifioides Speg. Later Kendrick \& Carmichael (1973) incorrectly placed this genus as a synonym of Tridentaria. But van der Aa \& van Oorschot (1985) and van der Aa \& von Arx (1986) maintained Fumagopsis as an acceptable genus with its unique charaterestics, setose sporodochial conidiomata surrounding the sporodochia. Tridentaria produces mononematous conidiophores and colonies

Table 1. Difference of conidia and conidial chain in genus Phalangispora.

\begin{tabular}{|l|l|l|}
\hline Species & Conidia size $(\mu \mathrm{m})$ & Conidial chain size $(\mu \mathrm{m})$ \\
\hline P. constricta & $11-20 \times 2.5-4$ & $120-140 \times 3-4$ \\
\hline P. nawawi & $10-12 \times 2$ (6 to 8 cells) & $65-90 \times 2$ \\
\hline P. bharathensis & $\begin{array}{l}8-10 \times 2.5-4 \text { (8 to } 11 \text { cells } \\
\text { mostly 9) }\end{array}$ & $75-85 \times 2.5-4$ \\
\hline Present study & $\begin{array}{l}8-12.5 \times 2-4.5 \text { (8 to 9 cells } \\
\text { mostly } 8)\end{array}$ & $74-87.5 \times 2-4.5$ \\
\hline
\end{tabular}


are without setae. However, in the present study considering the conidial shape, size (extend beyond type strain) and conidial chain length in AMH 9580; the new collection is placed under the species $P$. bharathensis.

\section{References}

Dahanukar, N. \& A. Padhye (2005). Amphibian diversity and distribution in Tamhini, northern Western Ghats, India. Current Science 88(9): 1496-1501.

Dixon, P.A. (1959). Stream spora in Ghana. Transactions of British Mycological Society 42: 174-176.

Ingold, C.T. (1959). Aquatic spora of Omo Forest, Nigeria. Transactions of British Mycological Society 42: 479-485.

Kendrick, W.B. \& J.W. Carmichael (1973). Hyphomycetes, Chapter 10, pp.323-509. In: Ainsworth, G.C., F.K. Sparrow \& A. S. Sussman (eds.). The Fungi - Vol. IVA. Academic Press, New York.

Kuthubutheen, A.J. (1987). A new species of Phalangispora and further observations on $P$. constricta from Malaysia. Transactions of British Mycological Society 89: 414-420.

Le-John, H.B. (1965). Sierra Leone freshwater hyphomycetes. Transactions of British Mycological Society 48: 261-264.

Miura, K. (1974). Stream spora of Japan. Transactions of the Mycological Society of Japan 15: 289-308.

Nawawi, A. \& J. Webster (1982). Phalangispora constricta gen. et. sp. nov., a sporodochial hyphomycete with branched conidia. Transactions of British Mycological Society 79: 65-68.
Nawawi, A. (1985). Aquatic hyphomycetes and other water-borne fungi from Malaysia. Malayan Nature Journal 39: 75-134.

Nayo, S.G. (1975). The Ecology and Distribution of Aquatic Hyphomycetes Around Bogor. Biotrop. SEAMEO Regional Centre for Tropical Biology, Bogor, Indonesia, 122pp.

Prasad, T.S.K. \& D.J. Bhat (2002). A new species of Phalangispora from India. Mycotaxon 83: 405-408.

Rajeshkumar, K.C. \& R. Sharma (2013). Tamhinispora a new genus belongs to family Tubeufiaceae from the Western Ghats, India based on morphology and phylogenetic analysis. Mycosphere 4(2): 1-10; http://dx.doi.org/10.5943/mycosphere/4/2/2

Rajeshkumar, K.C. \& S.K. Singh (2012). Manoharachariella indica sp. nov. from the Western Ghats, India. Mycotaxon 120: 43-48; http:// dx.doi.org/10.5248/120.43

Rajeshkumar, K.C., H.P. Rahul, G.B. Subhash, S.K. Singh (2011a). Pilidiella crousii sp. nov. from the northern Western Ghats, India. Mycotaxon 115, 155-162. http://dx.doi.org/10.5248/115.155.

Rajeshkumar, K.C., H.P. Rahul, S.V. Swami, P.N. Singh \& S.K. Singh (2011b). Morphology and molecular studies on Pseudocercospora kamalii sp. nov. a foliar pathogen on Terminalia from India. Mycotaxon 117: 227-237; http://dx.doi.org/10.5248/117.227

Seifert, K., G. Morgan-Jones, W. Gams \& B. Kendrick (2011). The Genera of Hyphomycetes. CBS Biodiversity Series 9: 1-997.

Spegazzini, C. (1910). Mycetes Argentinensis. Anales del Museo Nacional de Historia Natural de Buenos Aires 13: 329-467.

van der Aa, H.A. \& C.A.N. van Oorschot (1985). A redescription of some genera with staurospores. Persoonia 12: 415-425.

van der Aa, H.A. \& J.A. von Arx (1986). On Vonarxia, Kazulia and other fungi with stauroconidia. Persoonia 13: 127-128. 